\title{
Structural and Vibrational Study on Monomer and Dimer Forms and Water Clusters of Acetazolamide
}

\author{
Aysen E. Ozel, ${ }^{1}$ Serda Kecel Gunduz, ${ }^{1}$ Sefa Celik, ${ }^{2}$ and Sevim Akyuz ${ }^{3}$ \\ ${ }^{1}$ Physics Department, Science Faculty, Istanbul University, Vezneciler, 34134 Istanbul, Turkey \\ ${ }^{2}$ Electrical-Electronics Eng. Department, Engineering Faculty, Istanbul University, Avcilar, 34320 Istanbul, Turkey \\ ${ }^{3}$ Physics Department, Science and Letters Faculty, Istanbul Kultur University, Atakoy Campus, Bakirkoy, 34156 Istanbul, Turkey
}

Correspondence should be addressed to Aysen E. Ozel; aozel@istanbul.edu.tr

Received 24 June 2013; Revised 6 September 2013; Accepted 7 October 2013

Academic Editor: Shin ichi Morita

Copyright (C) 2013 Aysen E. Ozel et al. This is an open access article distributed under the Creative Commons Attribution License, which permits unrestricted use, distribution, and reproduction in any medium, provided the original work is properly cited.

Experimental IR and Raman spectra of solid acetazolamide have been analysed by computing the molecular structures and vibrational spectra of monomer and dimer forms and water clusters of acetazolamide. The possible stable conformers of free acetazolamide molecule in the ground state were obtained by scanning the potential energy surface through the dihedral angles, $\mathrm{D}_{1}$ (1S-2C-6S-9N), $\mathrm{D}_{2}(4 \mathrm{~N}-5 \mathrm{C}-12 \mathrm{~N}-14 \mathrm{C})$, and $\mathrm{D}_{3}$ (5C-12N-14C-16C). The final geometry parameters for the obtained stable conformers were determined by means of geometry optimization, carried out at DFT/B3LYP/6-31G++(d,p) theory level. Afterwards the possible dimer forms of the molecule and acetazolamide- $\mathrm{H}_{2} \mathrm{O}$ clusters were formed and their energetically preferred conformations were investigated using the same method and the same level of theory. The effect of BSSE on the structure and energy of acetazolamide dimer has been investigated. The assignment of the vibrational modes was performed based on the potential energy distribution of the vibrational modes, calculated by using GAR2PED program. The experimental vibrational wavenumbers of solid acetazolamide are found to be in better agreement with the calculated wavenumbers of dimer form of acetazolamide than those of its monomeric form. NBO analysis has been performed on both monomer and dimer geometries.

\section{Introduction}

Acetazolamide, $\mathrm{C}_{4} \mathrm{H}_{6} \mathrm{~N}_{4} \mathrm{O}_{3} \mathrm{~S}_{2}$ (1,3,4-thiadiazole-2-sulfonamide,5-acetamido), is a sulfonamide derivative and carbonic anhydrase inhibitor used clinically to lower intraocular pressure in glaucomatous patients. It is also used as a diuretic agent for treating acute high-altitude sickness and used for the treatment of epilepsy, and most frequently it is used as a drug for the prophylaxis of high-altitude disorders [1-3]. Recently, it has played a major role as a remedy against respiratory diseases and it has been used to prevent adverse effects of drugs in the treatment of influenza [4] and epilepsy and as diuretic [5]. Traditionally, carbonic anhydrase inhibitors derived from acetazolamide were shown to inhibit the growth of several tumor cell lines in vitro and in vivo $[6,7]$.

Acetazolamide is known to exist in two crystal forms (modifications I and II), which was first reported by Pala in 1956 [8]. Mathew and Palenik solved the crystal structure of triclinic acetazolamide (polymorphic form A, modification II) [9]. Griesser et al. [10] reported the crystal structure of acetazolamide polymorphic form B (modification I) and notified that crystal polymorphism of acetazolamide was based on changes in the spatial molecular arrangement and in the connectivities of hydrogen bonds. The experimental and calculated vibrational spectra [11] and crystal structure [12] of an acetazolamide derivative (5-amino-1,3,4-thiadiazole2-sulfonamide; Hats) have been reported. The experimental vibrational spectra of the two polymorphic forms (A, B) of acetazolamide were reported by Baraldi et al. [13]. The structure and spectroscopic behaviours of some 1,3,4thiadiazole ligands containing $-\mathrm{SO}_{2} \mathrm{NH}_{2}$ groups and their metal clusters were examined [14-23]. Recently, Brandan et al. [24] calculated the harmonic vibrational wavenumbers for the optimized geometry of acetazolamide, using DFT/B3LYP method with the $6-31 \mathrm{G}^{*}$ and $6-311++\mathrm{G}^{* *}$ basis sets. Chaturvedi et al. [25] reported calculated vibrational spectra of monomer and dimer forms of acetazolamide, 
but the calculations were performed on the most stable conformer, obtained by geometry optimization, and on three possible dimers. The basis set superposition error (BSSE) correction was not taken into account on the dimer forms. In the present work, we have extended the investigation of the possible stable conformers of title molecule by means of torsion potential energy surface scan studies through dihedral angles, $D_{1}(1 S-2 C-6 S-9 N), D_{2}(4 N-5 C-12 N-14 C)$, and $D_{3}$ (5C-12N-14C-16C), and calculated the vibrational modes and wavenumbers of the most stable conformer. Moreover, the structures and vibrational wavenumbers of four energetically favorable dimers and ten $\mathrm{H}_{2} \mathrm{O}$ clusters of acetazolamide were investigated and the effect of basis set superposition error (BSSE) on the structure and energy of acetazolamide dimers has been evaluated. Acetazolamide is very slightly soluble in water. However, its solubility is significantly important and its slight changes affect the bioavailability of acetazolamide [10]. The aims of this study are to elucidate the conformational preferences of acetazolamide and the effect of hydrogen bonding in the formation of molecular dimers and upon interaction with water molecules.

\section{Experimental and Computational Methods}

2.1. Experimental Part. The acetazolamide molecule was purchased from Sigma-Aldrich ( $\geq \% 99$ ) with CAS number 59-665 and used as received. The FT-IR spectra of $\mathrm{KBr}$ disc (for solid sample) and aqueous solution (between $\mathrm{ZnSe}$ plates) of the molecule were recorded on a Jasco FT/IR-6300 spectrometer in the range $400-4000 \mathrm{~cm}^{-1}$ with a resolution of $2 \mathrm{~cm}^{-1}$ based on averaging 200 samples and 100 background scans. The Raman spectrum of the sample was taken with a Jasco NRS-3100 micro-Raman spectrometer (1800 lines/mm or 1200 lines/mm grating and high sensitivity cooled CCD). Sample was excited with a $531.96 \mathrm{~nm}$ diode laser. The Raman system was calibrated with a silicon semiconductor using the Raman peak at $520 \mathrm{~cm}^{-1}$. A 20x microscope objective (Olympus) was used to focus the laser and collect Raman scattering on the sample. Spectral resolution was $1.08 \mathrm{~cm}^{-1}$ and 100 spectra were accumulated.

2.2. Computational Part. All of the calculations were carried out by using the Gaussian03@ program suite [26]. Due to success in calculating the electronic structure and energy, the calculations were carried out by using the hybrid density functional theory (DFT/B3LYP) method. For the calculations of monomer, dimer forms of acetazolamide and acetazolamidewater clusters $6-31++\mathrm{G}(\mathrm{d}, \mathrm{p})$ basis set was used. The X-ray crystallographic results [9] of acetazolamide molecule were used as initial input geometrical data. The minimum energy conformers of acetazolamide were identified by scanning the potential energy surface by varying $\mathrm{D}_{1}(1 \mathrm{~S}-2 \mathrm{C}-6 \mathrm{~S}-9 \mathrm{~N})$, $\mathrm{D}_{2}$ (4N-5C-12N-14C), and $\mathrm{D}_{3}$ (5C-12N-14C-16C) dihedral angles. The final geometry parameters for the obtained stable conformers were determined by means of geometry optimization carried out at DFT/B3LYP/6-31G++(d,p) level of theory. Furthermore, acetazolamide dimers were constructed by bringing two identical acetazolamide monomers

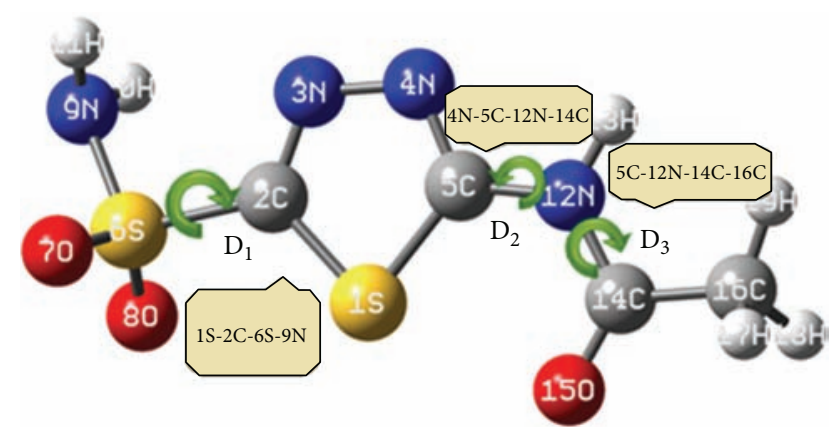

FIGURE 1: The most stable geometry, atom numbering, and searched dihedral angles of acetazolamide.

together in possible configurations, and energetically preferred conformations of dimers were investigated using the same method and the same level of theory. In order to correct overestimation between unscaled and observed wavenumbers dual scaling factors were used. We scaled all the computed harmonic wavenumbers under $1800 \mathrm{~cm}^{-1}$ with the scale factor 0.977 and wavenumbers greater than $1800 \mathrm{~cm}^{-1}$ with the scale factor 0.955 [27]. The potential energy distribution (PED) of the vibrational modes of the molecules was calculated with GAR2PED program [28], and the fundamental vibrational modes were characterized by their PED values.

\section{Result and Discussion}

3.1. Conformational Analysis and H-Bonding Interactions. The molecular model of acetazolamide with the atom numbering scheme is given in Figure 1. Stable low energy conformers of free acetazolamide molecule were obtained firstly by potential energy surface scan studies by iteratively varying $\mathrm{D}_{1}(1 \mathrm{~S}-2 \mathrm{C}-6 \mathrm{~S}-9 \mathrm{~N}), \mathrm{D}_{2}(4 \mathrm{~N}-5 \mathrm{C}-12 \mathrm{~N}-14 \mathrm{C})$, and $\mathrm{D}_{3}$ (5C-12N-14C-16C) dihedral angles with step angle of $60^{\circ}$. PES scan for acetazolamide calculated with $\mathrm{D}_{1}$ (1S-2C$6 \mathrm{~S}-9 \mathrm{~N}), \mathrm{D}_{2}$ (4N-5C-12N-14C), and $\mathrm{D}_{3}$ (5C-12N-14C-16C) dihedral angles at the B3LYP/6-31G++ $(\mathrm{d}, \mathrm{p})$ method is shown in Figure S1 (see Figure S1 in Supplementary Materials available online at http://dx.doi.org/10.1155/2013/538917). The 45 conformers were identified between 0 and $10 \mathrm{kcal} / \mathrm{mol}$ relative energy intervals. Their dihedral angles and relative energies were given in Table S1. The geometry optimization was then performed on the lowest energy conformer. The estimated four most stable conformers of acetazolamide dimers are illustrated in Figure 2. All possible conformations of acetazolamide interacting with one water molecule were investigated, and acetazolamide interacting with five water molecules was determined as the final possible conformation of acetazolamide-water cluster. Figure 3 demonstrates the geometries of the 10 stable acetazolamide-water clusters obtained using DFT method with B3LYP/6-31++G(d,p) basis set. The energies of the four most stable dimers (I-IV) and energetically preferred $\mathrm{H}_{2} \mathrm{O}$-acetazolamide clusters are given in Table 1. It is known that the basis set superposition error 


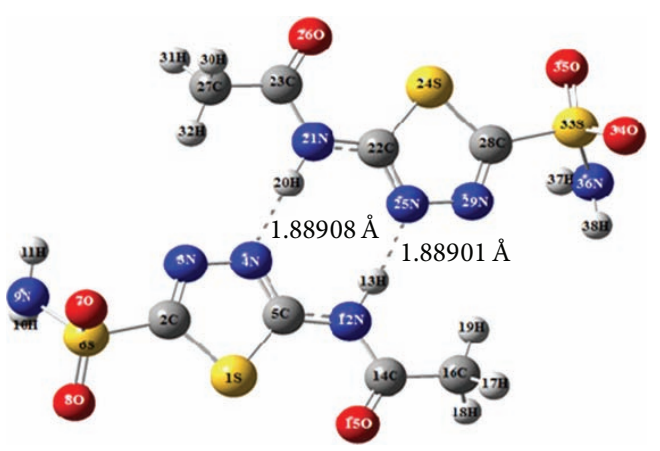

(I)

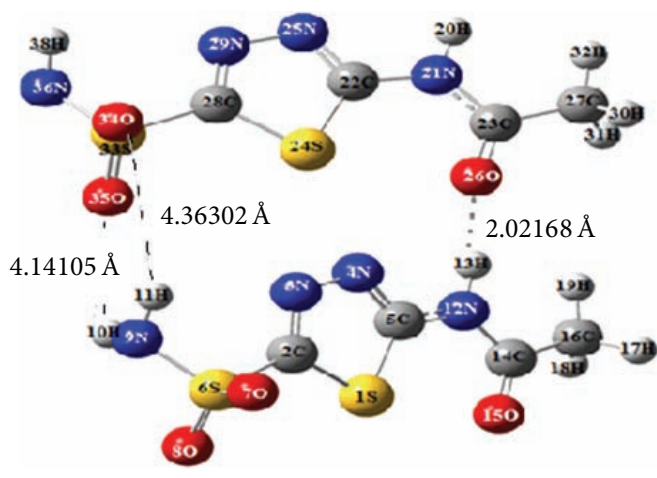

(III)

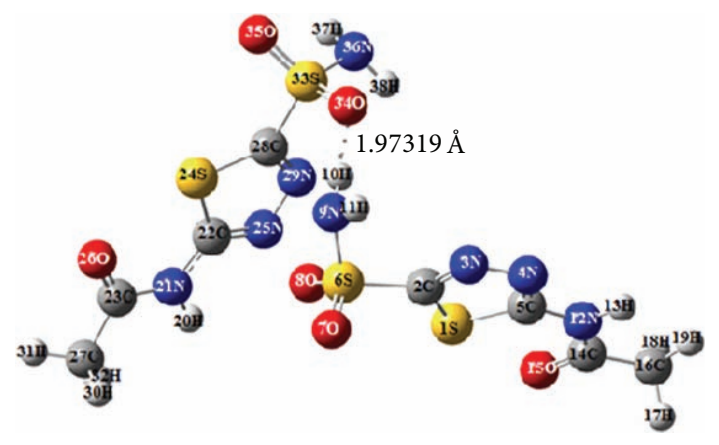

(II)

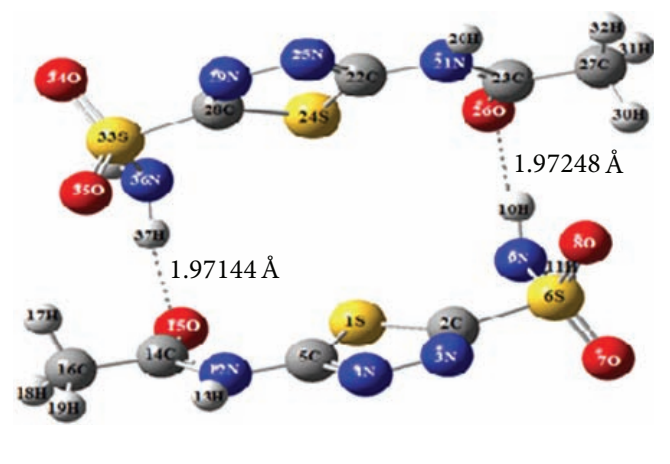

(IV)

FIGURE 2: The energy minimized structures of four low energy conformers (I-IV) of the dimer forms of the acetazolamide, (I-IV), respectively.

TABLE 1: (a) The calculated energies of monomeric, dimeric (I-IV), and $\mathrm{H}_{2} \mathrm{O}$ clusters (I-IX). (b) The counterpoise uncorrected and corrected interatomic distance $(\AA)$ and binding energy $(\mathrm{kcal} / \mathrm{mol})$ of dimer I.

(a)

\begin{tabular}{lcc}
\hline & Calculated energy $(\mathrm{kcal} / \mathrm{mol})$ & Energy differences $(\mathrm{kcal} / \mathrm{mol})$ \\
\hline Monomer & -876645.7 & - \\
Dimer I & -1753308.7 & $\mathbf{0}$ \\
Dimer II & -1753299.4 & 9.3 \\
Dimer III & -1753297.9 & 10.8 \\
Dimer IV & -1753301.5 & 7.2 \\
Cluster I & -924613.6 & 6.1 \\
Cluster II & -924617.1 & 2.6 \\
Cluster III & -924613.6 & 6.0 \\
Cluster IV & -924614.6 & 5.1 \\
Cluster V & -924619.1 & 0.6 \\
Cluster VI & -924619.7 & $\mathbf{0}$ \\
Cluster VII & -924619.1 & \\
Cluster VIII & -924612.9 & 0.6 \\
Cluster IX & -924614.6 & 6.7
\end{tabular}

(b)

\begin{tabular}{ccccc}
\hline & \multicolumn{2}{c}{ BSSE uncorrected } & \multicolumn{2}{c}{ BSSE corrected } \\
& $R(5 \mathrm{C}-22 \mathrm{C})(\AA)$ & $\Delta E(\mathrm{kcal} / \mathrm{mol})$ & $R(5 \mathrm{C}-22 \mathrm{C})(\AA)$ & $\Delta(E+\mathrm{BSSE})(\mathrm{kcal} / \mathrm{mol})$ \\
\hline Dimer I & 4.23 & 17.4 & 4.25 & 16.1 \\
\hline
\end{tabular}




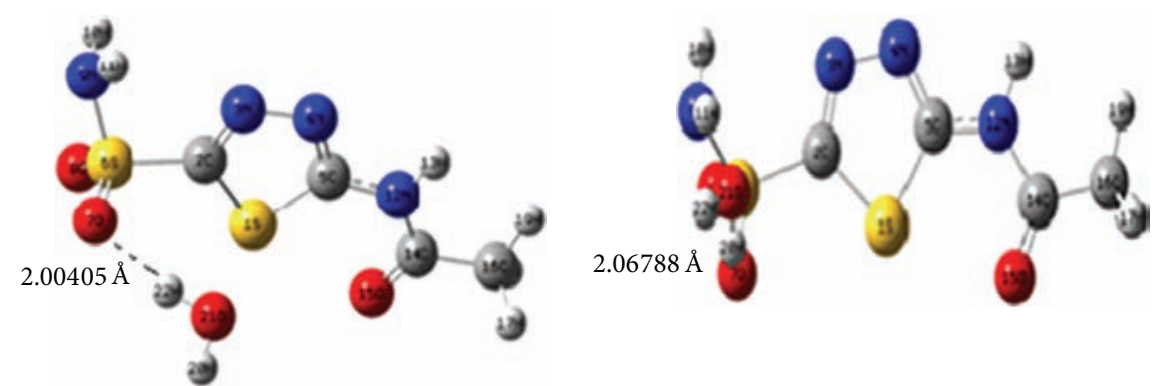

(I)

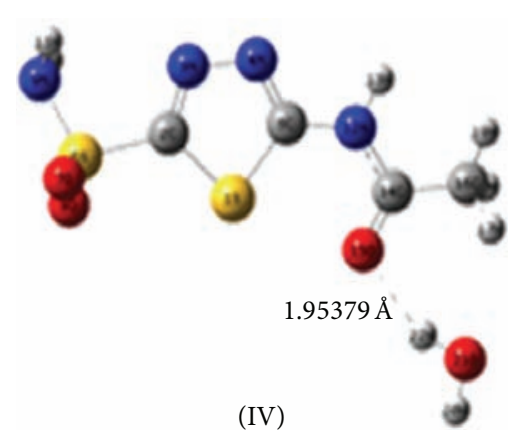

(IV)

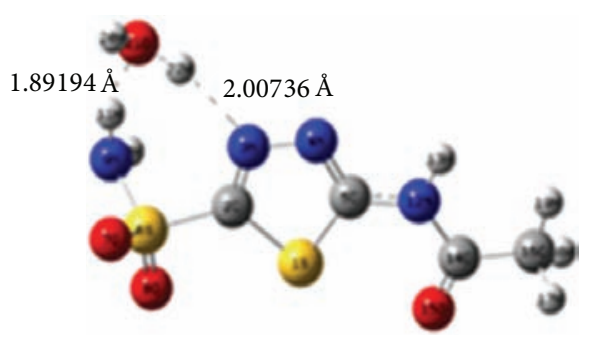

(VII)
(II)

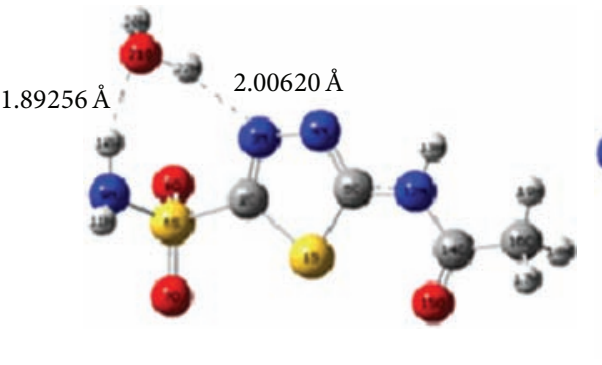

$(\mathrm{V})$

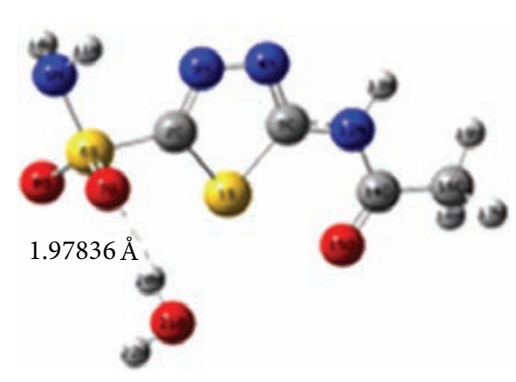

(VIII)

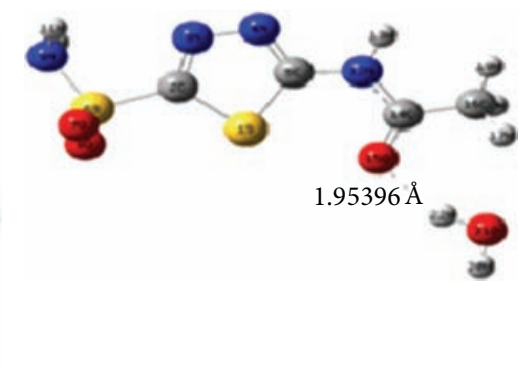

(IX)

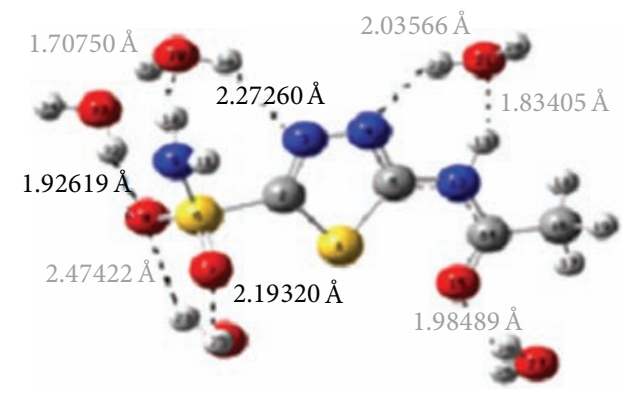

(X)

FIGURE 3: The energy minimized structures of ten low energy conformers (I-X) of $\mathrm{H}_{2} \mathrm{O}$ clusters of the acetazolamide (I-X), respectively.

(BSSE) effect is rather significant on the structure and energy of dimer forms, so removing this effect is very important. Therefore, optimization of the dimer I was also carried out along with the counterpoise correction scheme proposed by Boys and Bernardi [29]. The BSSE uncorrected and corrected distances between two acetazolamide units $\{R(5 \mathrm{C}-22 \mathrm{C})(\AA)\}$ and binding energy $(\Delta E)$ of acetazolamide dimer $\{\Delta E=$ $\left.2^{*} E_{\text {monomer }}-E_{\text {dimer }}\right\}$ are given in Table 1(b). As seen in Table 1(b), the energy of dimer I is found to be $17.39 \mathrm{kcal} / \mathrm{mol}$ lower then total energy of the two monomer $\left(2^{*} E_{\text {monomer }}\right)$ units, indicating that intermolecular hydrogen bonding plays an important role in stabilization of the molecule.

The predicted geometrical parameters such as bond lengths and bond angles of the stable conformation of acetazolamide monomer, dimer (dimer I), and water cluster (VI and X) of acetazolamide, calculated at B3LYP method with $6-31 \mathrm{G}++(\mathrm{d}, \mathrm{p})$, are presented in Table $\mathrm{S} 2$ in accordance with the atom numbering scheme as given in Figure 1. By 

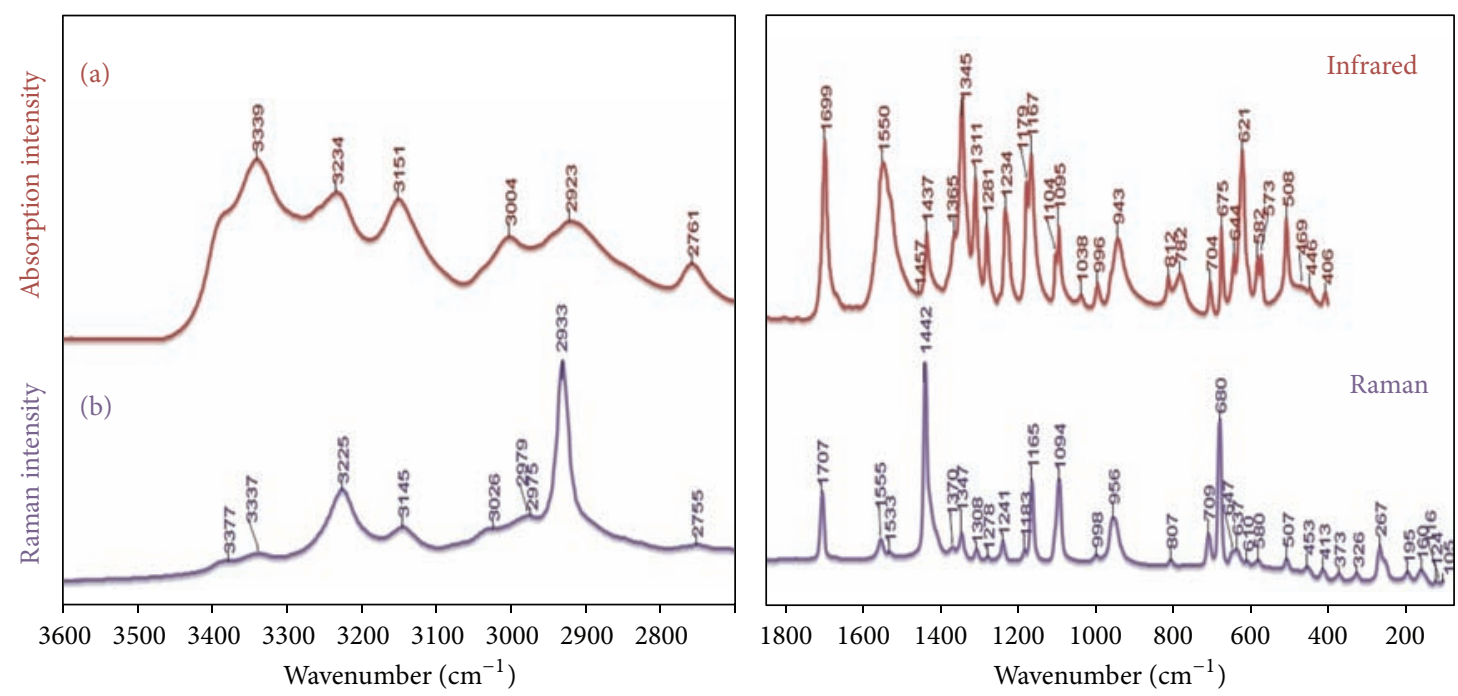

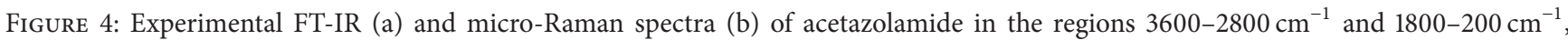
respectively.

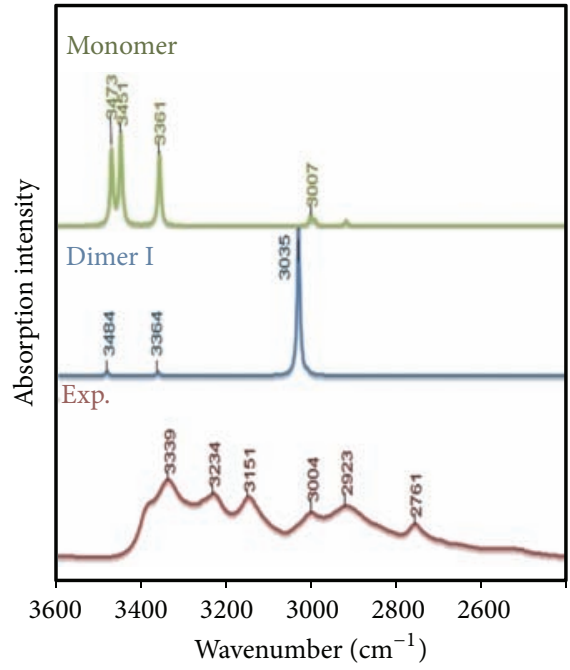

(a)

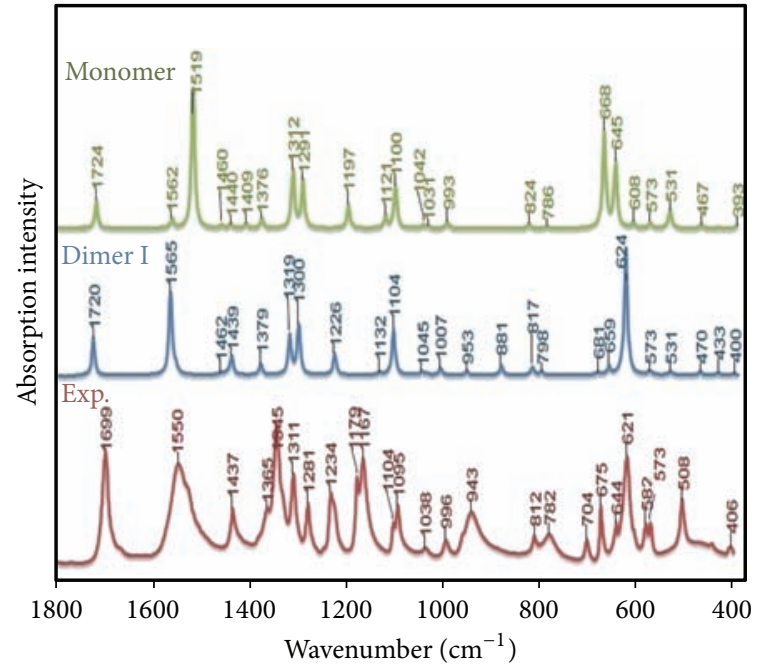

(b)

FIGURE 5: Experimental FT-IR (solid) and calculated (scaled) absorption intensity spectra of acetazolamide in the regions $3600-2600 \mathrm{~cm}^{-1}$ (a) and 1800-400 $\mathrm{cm}^{-1}$ (b), respectively.

comparing theoretical and experimental bond lengths [9], it is easily seen that the computed bond lengths at B3LYP/6$31++G(d, p)$ method were slightly longer since the theoretical calculations were performed on isolated molecule in the gaseous state, whereas the experimental results are for the solid phase of the molecule $[9,10,12]$. Main differences between crystal structure [9] and monomer acetazolamide occur in $\mathrm{H}$ containing bond lengths and angles, and this is probably due to insufficient predictions for light atoms in the crystal structure study done in 1974 [9]. The theoretical results are mainly consistent with reports of other studies [11, 24]. Comparison of the geometry parameters of monomer form with those of dimer and water cluster of acetazolamide clearly shows the effects of intermolecular hydrogen bonding.
The intra- and intermolecular hydrogen bonds of the dimer forms (I-IV) of the four low energy conformations together with those of ten energetically preferred water clusters are tabulated in Table 2. The lowest energy conformer of dimer form (dimer I) makes stronger interhydrogen bonding interactions.

3.2. Vibrational Analysis. The experimental FT-IR (a) and micro-Raman spectra (b) of acetazolamide are given in Figure 4. The experimental FT-IR and Raman spectra of the solid acetazolamide are also given in comparison with those of calculated gas phase spectra in Figures 5 and 6, respectively.

The calculated wavenumbers, the calculated Raman intensities, and the potential energy distributions of the 


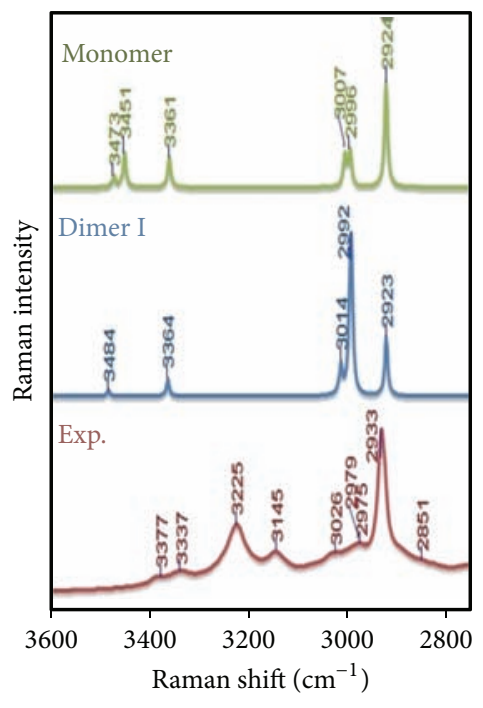

(a)

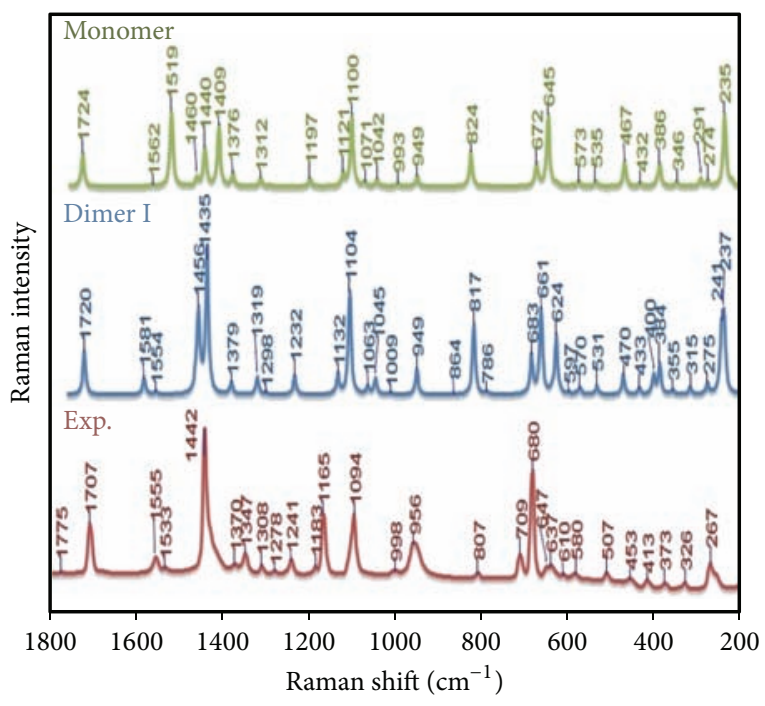

(b)

FIGURE 6: Experimental (solid) and calculated (scaled) Raman intensities spectra of acetazolamide in the regions $3600-2800 \mathrm{~cm}^{-1}$ (a) and $1800-200 \mathrm{~cm}^{-1}$ (b), respectively.

vibrational modes of monomer and dimer (I) forms of acetazolamide and acetazolamide- $\mathrm{H}_{2} \mathrm{O}$ cluster (VI and X) are given in Table 3 , in comparison with the experimental vibrational spectra of the investigated molecule. The calculated wavenumbers of the four low energy dimers of acetazolamide are given in Table S3 comparatively. The assignment procedure for the dimers was done according to the potential energy distribution of dimer I.

When acetazolamide goes from the monomer form to the dimer or to the water cluster, alterations in the vibrational spectra, due to formation of $\mathrm{H}$-bonds, are estimated. The $\mathrm{NH}_{2}, \mathrm{NH}, \mathrm{C}=\mathrm{O}$, and $\mathrm{SO}_{2}$ vibrational modes provide useful information on the intermolecular $\mathrm{H}$-bonding interaction for the acetazolamide. On the other hand, NH stretching vibrations have anharmonic behavior [30-32]. Thus, in harmonic approximation procedure, $\mathrm{NH}_{2}$ stretching wavenumbers are overestimated due to neglect of anharmonicity [33]. The calculated values of $v(\mathrm{NH})$ stretching wavenumbers were $3451,3035-2995$ and $3221 \mathrm{~cm}^{-1}$ and $3099 \mathrm{~cm}^{-1}$ for monomer and dimer (dimer I) forms and water cluster (VI and X), respectively. As seen from Table 3, due to the participation of the $-\mathrm{NH}$ group in hydrogen bonds, $\nu(\mathrm{NH})$ in dimer I (with two N...H bonds; Figure 2) and water clusters VI and X (Figure 3) showed negative shifts, 456-416 and $230 \mathrm{~cm}^{-1}$ and $352 \mathrm{~cm}^{-1}$, respectively. The highest shifts (456 and $416 \mathrm{~cm}^{-1}$ ) were obtained for the dimer I. The calculated values suggest the presence of relatively strong $\mathrm{N} \cdots \mathrm{H}$ and $\mathrm{NH} \cdots \mathrm{N}$ hydrogen bond interactions in dimer I. The differences in hydrogen bonding strengths are responsible for these different wavenumber shifts. On the other hand $\mathrm{C}=\mathrm{O}$, and $\mathrm{SO}_{2}$ groups do not involve hydrogen bonding interaction in both dimer I form and water cluster VI, and we do not observe a remarkable change in this wavenumber on going from monomer form to dimer or cluster form.

The acetazolamide $\mathrm{C}-\mathrm{N}$ ring stretching modes were recorded at $1540 \mathrm{~cm}^{-1}, 1425 \mathrm{~cm}^{-1}$, and $1275 \mathrm{~cm}^{-1}$ as strong intense bands in the IR and at $1425 \mathrm{~cm}^{-1}$ and $1260 \mathrm{~cm}^{-1}$ in Raman spectra of solid acetazolamide by Chufan et al. [19]. However, in other studies, these modes were obtained at $1498 \mathrm{~cm}^{-1}$ and $1450 \mathrm{~cm}^{-1}$ [11] and at $1571 \mathrm{~cm}^{-1}$ and $1452 \mathrm{~cm}^{-1}$ [34]. In the present study, the 1550, 1420, 1384, and $1311 \mathrm{~cm}^{-1}$ in IR and 1555, 1428, 1370, and $1308 \mathrm{~cm}^{-1}$ in Raman spectrum of solid acetazolamide are assigned to $\mathrm{C}-\mathrm{N}$ stretching vibrations. The $1550 \mathrm{~cm}^{-1}$ (IR) $\mathrm{C}-\mathrm{N}$ stretching mode is estimated to shift to higher wavenumber in both dimer and water cluster forms due to contribution of $\delta_{\mathrm{CNH}}$ mode.

The $v_{\mathrm{as}}\left(\mathrm{SO}_{2}\right)$ stretching mode was observed at $1345 \mathrm{~cm}^{-1}$ and $1347 \mathrm{~cm}^{-1}$ in IR and Raman spectra, respectively, and was calculated at $1312 \mathrm{~cm}^{-1}, 1314 \mathrm{~cm}^{-1}, 1296 \mathrm{~cm}^{-1}$, and $1319 \mathrm{~cm}^{-1}$ for monomer, clusters (VI and X), and dimer structure, respectively. Cami et al. [11] observed this mode at $1342 \mathrm{~cm}^{-1}$ and Baraldi recorded this mode at $1343 \mathrm{~cm}^{-1}$ and at $1348 \mathrm{~cm}^{-1}$ in IR and Raman spectra, respectively [13].

The mixing of $\delta_{\mathrm{CNH}}+\nu(\mathrm{C}-\mathrm{N})$ modes was observed at 1234 and $1226 \mathrm{~cm}^{-1}$ as a strong band in the IR spectrum and at $1241 \mathrm{~cm}^{-1}$ in Raman spectrum as a medium band. This mode is calculated at $1197,1223,1319$, and $1232-1226 \mathrm{~cm}^{-1}$ for free, clusters (VI and X), and dimer forms of acetazolamide, respectively.

The bands at $1174 \mathrm{~cm}^{-1}$ and $1140 \mathrm{~cm}^{-1}$ were assigned to $\nu(\mathrm{N}-\mathrm{N})_{\text {ring }}$ stretching and $\nu \mathrm{SO}_{2}$ symmetric stretching vibrations, respectively, by Cami et al. [11]. In this study we observed a strong band at $1167 \mathrm{~cm}^{-1}$ in IR and $1165 \mathrm{~cm}^{-1}$ in Raman spectra and assigned it to $\nu \mathrm{SO}_{2+} v(\mathrm{~N}-\mathrm{N})$ mode according to $\mathrm{PED}$ calculations. The $\mathrm{PED}$ result of this mode shows us that $\mathrm{SO}_{2}$ stretching and $(\mathrm{N}-\mathrm{N})$ stretching contributions are $59 \%$ and $44 \%$, respectively.

The strong band at $1095 \mathrm{~cm}^{-1}$ in the IR and Raman spectra is assigned to $\mathrm{NH}_{2}$ rocking mode, in agreement with PED. The corresponding mode was assigned at $1097 \mathrm{~cm}^{-1}$ [11] and at $1090 \mathrm{~cm}^{-1}$ [34] in previous studies. But Baraldi et al. 
TABLE 2: The intra- and interhydrogen bonds of the dimer conformers (I-IV) and $\mathrm{H}_{2} \mathrm{O}$ clusters (I-X) of acetazolamide.

(a)

\begin{tabular}{|c|c|c|c|c|c|c|c|}
\hline \multirow{3}{*}{\multicolumn{2}{|c|}{$\begin{array}{c}\text { Dimer I } \\
\text { Intramolecular } \\
\text { H-bonds }\end{array}$}} & \multicolumn{2}{|c|}{ Dimer II } & \multicolumn{2}{|c|}{ Dimer III } & \multicolumn{2}{|c|}{ Dimer IV } \\
\hline & & \multicolumn{2}{|c|}{ Intramolecular } & \multirow{2}{*}{\multicolumn{2}{|c|}{$\begin{array}{c}\text { Intramolecular } \\
\text { H-bonds }\end{array}$}} & \multicolumn{2}{|c|}{ Intramolecular } \\
\hline & & $\mathrm{H}-\mathrm{b}$ & & & & H-b & \\
\hline Atoms & Bond $(\AA)$ & Atoms & Bond $(\AA)$ & Atoms & Bond $(\AA)$ & Atoms & Bond $(\AA)$ \\
\hline $3 \mathrm{~N}-10 \mathrm{H}$ & 3.377 & $3 \mathrm{~N}-10 \mathrm{H}$ & 3.342 & $3 \mathrm{~N}-10 \mathrm{H}$ & 3.148 & $4 \mathrm{~N}-13 \mathrm{H}$ & 2.468 \\
\hline $3 \mathrm{~N}-11 \mathrm{H}$ & 2.975 & $3 \mathrm{~N}-11 \mathrm{H}$ & 2.962 & $3 \mathrm{~N}-11 \mathrm{H}$ & 2.816 & $20 \mathrm{H}-25 \mathrm{~N}$ & 2.468 \\
\hline $8 \mathrm{O}-10 \mathrm{H}$ & 2.698 & $8 \mathrm{O}-10 \mathrm{H}$ & 2.717 & $8 \mathrm{O}-10 \mathrm{H}$ & 2.700 & & \\
\hline $7 \mathrm{O}-11 \mathrm{H}$ & 2.696 & $7 \mathrm{O}-11 \mathrm{H}$ & 2.694 & $7 \mathrm{O}-11 \mathrm{H}$ & 2.715 & & \\
\hline $4 \mathrm{~N}-13 \mathrm{H}$ & 2.512 & $4 \mathrm{~N}-13 \mathrm{H}$ & 2.467 & $4 \mathrm{~N}-13 \mathrm{H}$ & 2.488 & & \\
\hline $29 \mathrm{~N}-37 \mathrm{H}$ & 3.377 & $29 \mathrm{~N}-37 \mathrm{H}$ & 3.196 & $29 \mathrm{~N}-37 \mathrm{H}$ & 3.141 & & \\
\hline $29 \mathrm{~N}-38 \mathrm{H}$ & 2.975 & $29 \mathrm{~N}-38 \mathrm{H}$ & 2.766 & $29 \mathrm{~N}-38 \mathrm{H}$ & 2.857 & & \\
\hline $35 \mathrm{O}-37 \mathrm{H}$ & 2.968 & $35 \mathrm{O}-37 \mathrm{H}$ & 2.689 & $35 \mathrm{O}-37 \mathrm{H}$ & 2.697 & & \\
\hline $34 \mathrm{O}-38 \mathrm{H}$ & 2.696 & $34 \mathrm{O}-38 \mathrm{H}$ & 2.717 & $34 \mathrm{O}-38 \mathrm{H}$ & 2.713 & & \\
\hline $20 \mathrm{H}-25 \mathrm{~N}$ & 2.512 & $20 \mathrm{H}-25 \mathrm{~N}$ & 2.476 & $20 \mathrm{H}-25 \mathrm{~N}$ & 2.458 & & \\
\hline \multicolumn{2}{|c|}{ H-bonds } & \multicolumn{2}{|c|}{ Intermolecular } & \multicolumn{2}{|c|}{ H-bonds } & \multicolumn{2}{|c|}{ H-bonds } \\
\hline $13 \mathrm{H}-25 \mathrm{~N}$ & 1.889 & $10 \mathrm{H}-34 \mathrm{O}$ & 1.973 & $10 \mathrm{H}-35 \mathrm{O}$ & 4.141 & $15 \mathrm{O}-37 \mathrm{H}$ & 1.971 \\
\hline \multirow[t]{3}{*}{$4 \mathrm{~N}-20 \mathrm{H}$} & 1.889 & $11 \mathrm{H}-35 \mathrm{O}$ & - & $11 \mathrm{H}-34 \mathrm{O}$ & 4.363 & $15 \mathrm{O}-38 \mathrm{H}$ & - \\
\hline & & & & $13 \mathrm{H}-26 \mathrm{O}$ & 2.022 & $10 \mathrm{H}-26 \mathrm{O}$ & 1.972 \\
\hline & & & & & & $11 \mathrm{H}-26 \mathrm{O}$ & - \\
\hline
\end{tabular}

(b)

\begin{tabular}{|c|c|c|c|c|c|c|c|c|c|}
\hline \multicolumn{2}{|c|}{$\begin{array}{c}\text { Cluster I } \\
\text { Intramolecular } \\
\text { H-bonds }\end{array}$} & \multicolumn{2}{|c|}{$\begin{array}{c}\text { Cluster II } \\
\text { Intramolecular } \\
\text { H-bonds }\end{array}$} & \multicolumn{2}{|c|}{$\begin{array}{c}\text { Cluster III } \\
\text { Intramolecular } \\
\text { H-bonds }\end{array}$} & \multicolumn{2}{|c|}{$\begin{array}{c}\text { Cluster IV } \\
\text { Intramolecular } \\
\text { H-bonds }\end{array}$} & \multicolumn{2}{|c|}{$\begin{array}{l}\text { Intramolecular } \\
\text { H-bonds }\end{array}$} \\
\hline Atoms & Bond $(\AA)$ & Atoms & Bond $(\AA)$ & Atoms & Bond $(\AA)$ & Atoms & Bond $(\AA)$ & Atoms & Bond $(\AA)$ \\
\hline $3 \mathrm{~N}-10 \mathrm{H}$ & 3.103 & $3 \mathrm{~N}-10 \mathrm{H}$ & 2.838 & $3 \mathrm{~N}-10 \mathrm{H}$ & 3.092 & $3 \mathrm{~N}-10 \mathrm{H}$ & 3.068 & $3 \mathrm{~N}-10 \mathrm{H}$ & 3.041 \\
\hline $3 \mathrm{~N}-11 \mathrm{H}$ & 2.786 & $3 \mathrm{~N}-11 \mathrm{H}$ & 3.340 & $3 \mathrm{~N}-11 \mathrm{H}$ & 2.791 & $3 \mathrm{~N}-11 \mathrm{H}$ & 2.846 & $3 \mathrm{~N}-11 \mathrm{H}$ & 3.593 \\
\hline $8 \mathrm{O}-10 \mathrm{H}$ & 2.696 & $8 \mathrm{O}-10 \mathrm{H}$ & 2.767 & $8 \mathrm{O}-10 \mathrm{H}$ & 2.695 & $8 \mathrm{O}-10 \mathrm{H}$ & 2.696 & $8 \mathrm{O}-10 \mathrm{H}$ & 2.733 \\
\hline $7 \mathrm{O}-11 \mathrm{H}$ & 2.715 & $7 \mathrm{O}-11 \mathrm{H}$ & 2.630 & $7 \mathrm{O}-11 \mathrm{H}$ & 2.716 & $7 \mathrm{O}-11 \mathrm{H}$ & 2.715 & $7 \mathrm{O}-11 \mathrm{H}$ & 2.659 \\
\hline $4 \mathrm{~N}-13 \mathrm{H}$ & 2.474 & $4 \mathrm{~N}-13 \mathrm{H}$ & 2.472 & $4 \mathrm{~N}-13 \mathrm{H}$ & 2.475 & $4 \mathrm{~N}-13 \mathrm{H}$ & 2.472 & $4 \mathrm{~N}-13 \mathrm{H}$ & 2.472 \\
\hline \multicolumn{2}{|c|}{$\begin{array}{c}\text { Intermolecular } \\
\text { H-bonds }\end{array}$} & \multicolumn{2}{|c|}{$\begin{array}{c}\text { Intermolecular } \\
\text { H-bonds }\end{array}$} & \multicolumn{2}{|c|}{$\begin{array}{c}\text { Intermolecular } \\
\text { H-bonds }\end{array}$} & \multicolumn{2}{|c|}{$\begin{array}{c}\text { Intermolecular } \\
\text { H-bonds }\end{array}$} & \multicolumn{2}{|c|}{$\begin{array}{c}\text { Intermolecular } \\
\text { H-bonds }\end{array}$} \\
\hline $7 \mathrm{O}-22 \mathrm{H}$ & 2.004 & $7 \mathrm{O}-20 \mathrm{H}$ & 2.068 & $7 \mathrm{O}-22 \mathrm{H}$ & 1.983 & $15 \mathrm{O}-22 \mathrm{H}$ & 1.954 & $\begin{array}{l}3 \mathrm{~N}-22 \mathrm{H} \\
10 \mathrm{H}-21 \mathrm{O}\end{array}$ & $\begin{array}{l}2.006 \\
1.893\end{array}$ \\
\hline \multicolumn{2}{|c|}{$\begin{array}{c}\text { Cluster VI } \\
\text { Intramolecular } \\
\text { H-bonds }\end{array}$} & \multicolumn{2}{|c|}{$\begin{array}{l}\text { Cluster VII } \\
\text { Intramolecular } \\
\text { H-bond }\end{array}$} & \multicolumn{2}{|c|}{$\begin{array}{l}\text { Cluster VIII } \\
\text { Intramolecular } \\
\text { H-bonds }\end{array}$} & \multicolumn{2}{|c|}{$\begin{array}{c}\text { Cluster IX } \\
\text { Intramolecular } \\
\text { H-bonds }\end{array}$} & \multicolumn{2}{|c|}{$\begin{array}{c}\text { Cluster X } \\
\left(5 \mathrm{H}_{2} \mathrm{O}\right) \\
\text { Intramolecular } \\
\text { H-bonds }\end{array}$} \\
\hline Atoms & Bond $(\AA)$ & Atoms & Bond $(\AA)$ & Atoms & Bond $(\AA)$ & Atoms & Bond $(\AA)$ & Atoms & Bond $(\AA)$ \\
\hline $3 \mathrm{~N}-10 \mathrm{H}$ & 3.175 & $3 \mathrm{~N}-10 \mathrm{H}$ & 3.591 & $3 \mathrm{~N}-10 \mathrm{H}$ & 2.999 & $3 \mathrm{~N}-10 \mathrm{H}$ & 3.068 & $3 \mathrm{~N}-10 \mathrm{H}$ & 2.837 \\
\hline $3 \mathrm{~N}-11 \mathrm{H}$ & 2.850 & $3 \mathrm{~N}-11 \mathrm{H}$ & 3.041 & $3 \mathrm{~N}-11 \mathrm{H}$ & 2.859 & $3 \mathrm{~N}-11 \mathrm{H}$ & 2.845 & $3 \mathrm{~N}-11 \mathrm{H}$ & 3.229 \\
\hline $8 \mathrm{O}-10 \mathrm{H}$ & 2.694 & $8 \mathrm{O}-10 \mathrm{H}$ & 2.659 & $8 \mathrm{O}-10 \mathrm{H}$ & 2.711 & $8 \mathrm{O}-10 \mathrm{H}$ & 2.695 & $8 \mathrm{O}-10 \mathrm{H}$ & 2.781 \\
\hline $7 \mathrm{O}-11 \mathrm{H}$ & 2.712 & $7 \mathrm{O}-11 \mathrm{H}$ & 2.732 & $7 \mathrm{O}-11 \mathrm{H}$ & 2.693 & $7 \mathrm{O}-11 \mathrm{H}$ & 2.716 & $7 \mathrm{O}-11 \mathrm{H}$ & 2.636 \\
\hline $4 \mathrm{~N}-13 \mathrm{H}$ & 2.487 & $4 \mathrm{~N}-13 \mathrm{H}$ & 2.472 & $4 \mathrm{~N}-13 \mathrm{H}$ & 2.478 & $4 \mathrm{~N}-13 \mathrm{H}$ & 2.472 & $4 \mathrm{~N}-13 \mathrm{H}$ & 2.463 \\
\hline \multicolumn{2}{|c|}{$\begin{array}{c}\text { Intermolecular } \\
\text { H-bonds }\end{array}$} & \multicolumn{2}{|c|}{$\begin{array}{c}\text { Intermolecular } \\
\text { H-bonds }\end{array}$} & \multicolumn{2}{|c|}{$\begin{array}{c}\text { Intermolecular } \\
\text { H-bonds }\end{array}$} & \multicolumn{2}{|c|}{$\begin{array}{c}\text { Intermolecular } \\
\text { H-bonds }\end{array}$} & \multicolumn{2}{|c|}{$\begin{array}{c}\text { Intermolecular } \\
\text { H-bonds }\end{array}$} \\
\hline $4 \mathrm{~N}-22 \mathrm{H}$ & 2.023 & $3 \mathrm{~N}-22 \mathrm{H}$ & 2.007 & $7 \mathrm{O}-20 \mathrm{H}$ & 1.978 & $15 \mathrm{O}-22 \mathrm{H}$ & 1.954 & $7 \mathrm{O}-25 \mathrm{H}$ & 2.193 \\
\hline \multirow[t]{7}{*}{$13 \mathrm{H}-21 \mathrm{O}$} & 1.907 & $11 \mathrm{H}-21 \mathrm{O}$ & 1.892 & & & & & $8 \mathrm{O}-32 \mathrm{H}$ & 1.926 \\
\hline & & & & & & & & $3 \mathrm{~N}-30 \mathrm{H}$ & 2.273 \\
\hline & & & & & & & & $10 \mathrm{H}-29 \mathrm{O}$ & 1.708 \\
\hline & & & & & & & & $4 \mathrm{~N}-22 \mathrm{H}$ & 2.036 \\
\hline & & & & & & & & $13 \mathrm{H}-21 \mathrm{O}$ & 1.834 \\
\hline & & & & & & & & $15 \mathrm{O}-28 \mathrm{H}$ & 1.985 \\
\hline & & & & & & & & $8 \mathrm{O}-23 \mathrm{H}$ & 2.474 \\
\hline
\end{tabular}




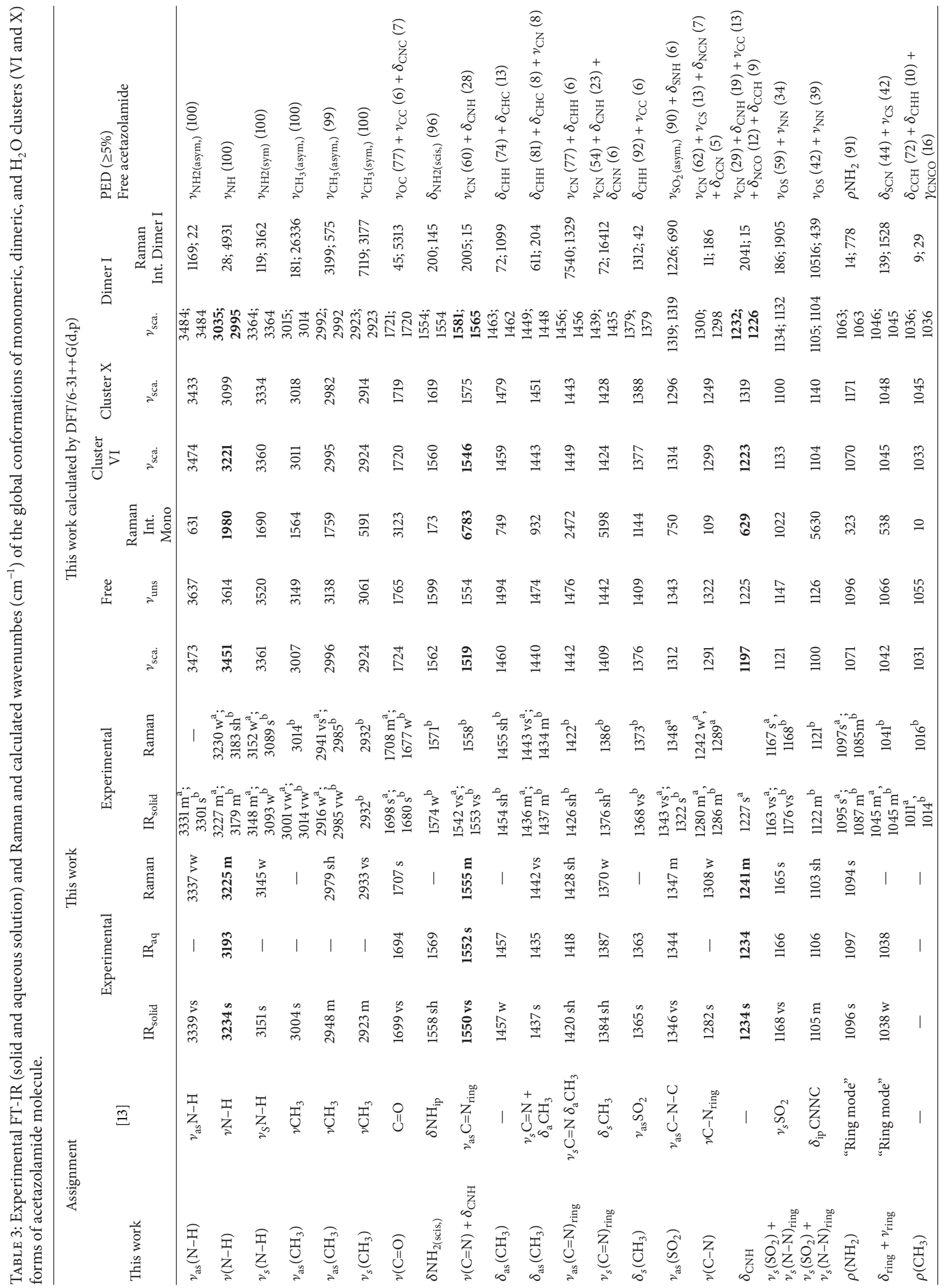




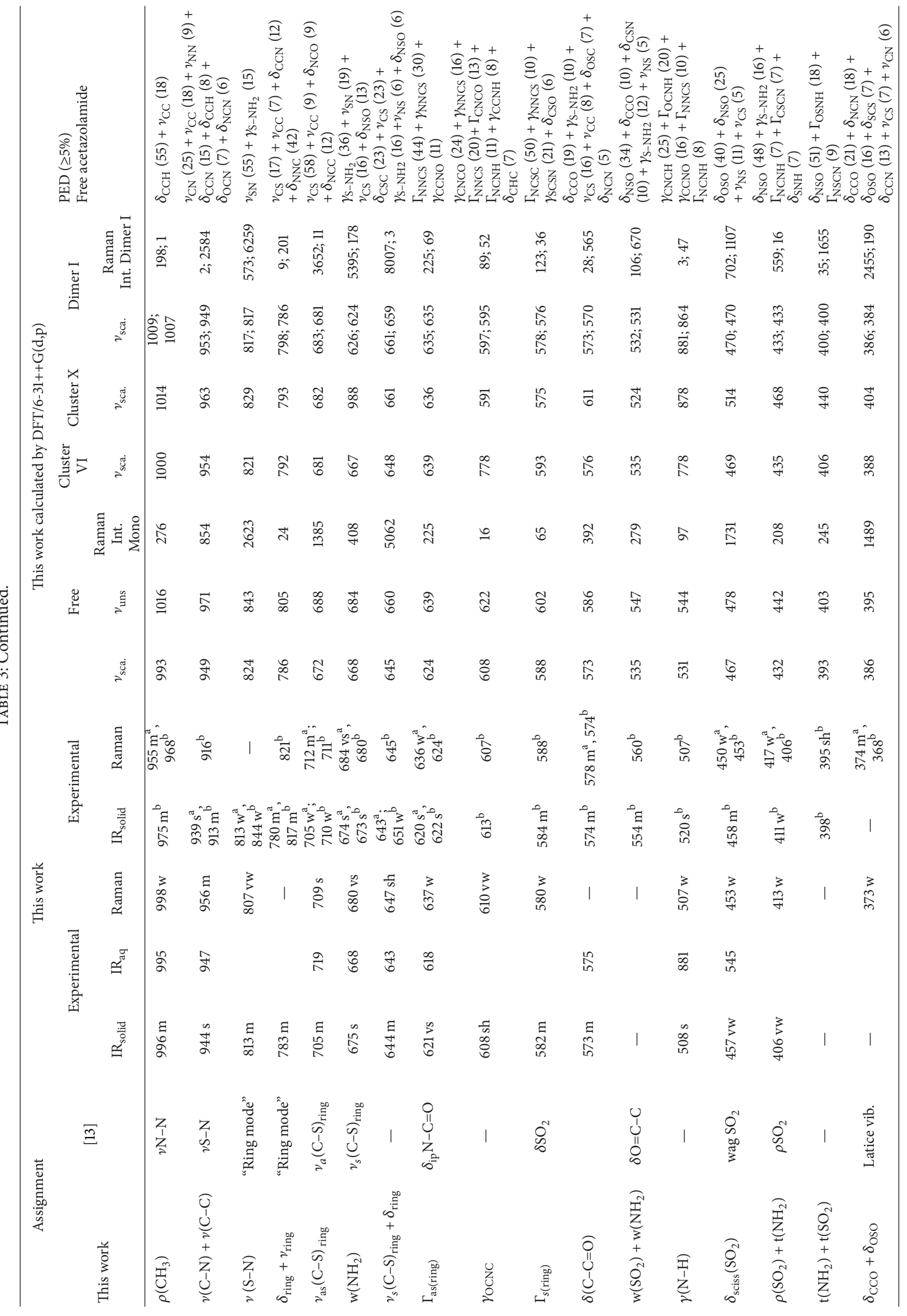




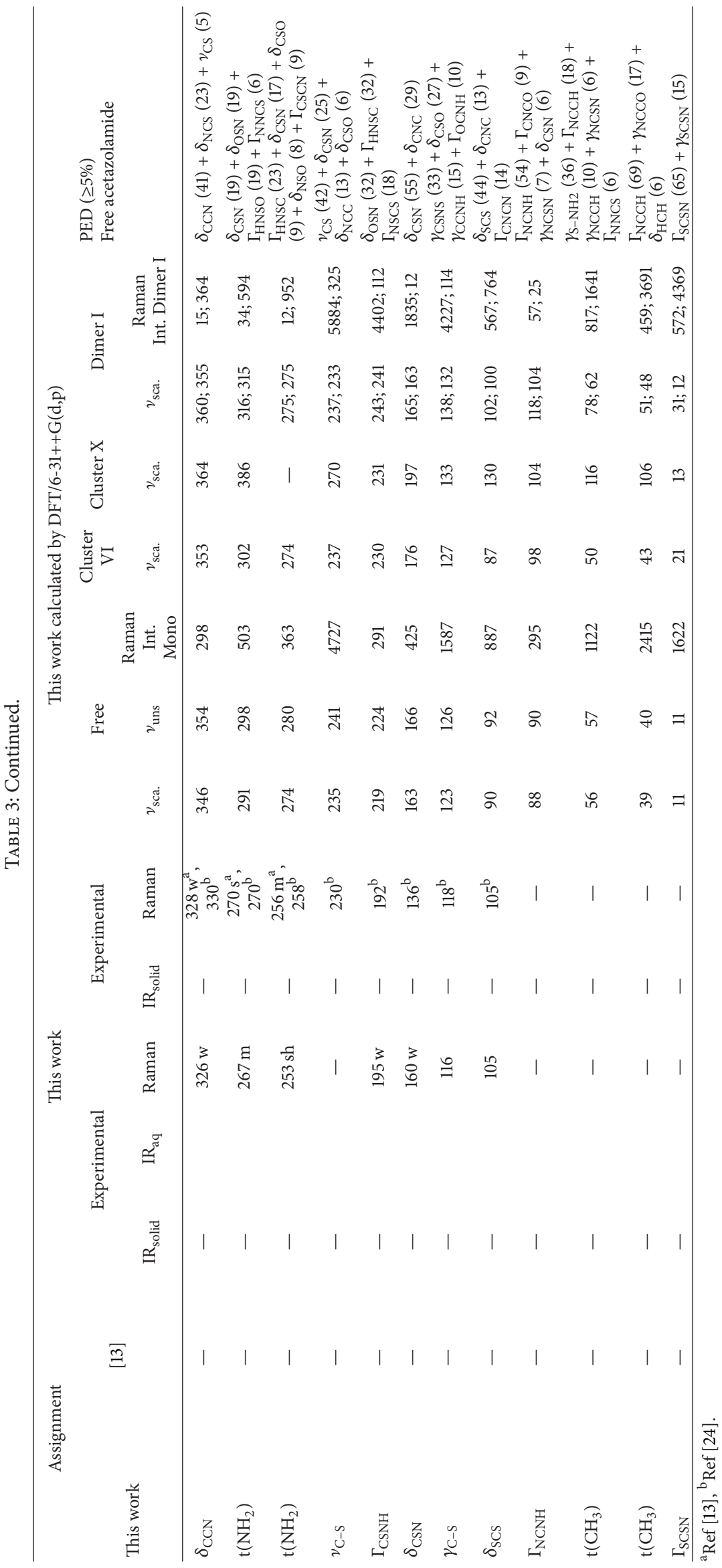


assigned this strong intense band at $1095 \mathrm{~cm}^{-1}$ to a "ring mode" (1,3,4 thiadiazolic ring) [13]. Our assignments are in agreement with those of Cami et al. [11,34].

Cami et al. [11] assigned the $1058 \mathrm{~cm}^{-1}$ and $795 \mathrm{~cm}^{-1}$ bands to ring bending vibrations with contribution from $\nu(\mathrm{C}-\mathrm{S})$ [11]. In this study, ring bending and ring stretching modes were found to be mixed and assigned to $1038 \mathrm{~cm}^{-1}$ and $782 \mathrm{~cm}^{-1}$ bands observed in IR spectrum as weak bands. We do not observe any band in the Raman spectrum attributable to these modes.

We assigned the $v(\mathrm{~S}-\mathrm{N})$ mode to the medium and weak bands observed at $812 \mathrm{~cm}^{-1}$ and $807 \mathrm{~cm}^{-1}$ in the IR and Raman spectra, respectively, according to the calculated results. This mode was assigned to the medium band at $872 \mathrm{~cm}^{-1}$ in [34], whereas Cami et al. [11] assigned the $v(\mathrm{~S}-$ $\mathrm{N})+$ wagging $\left(\mathrm{NH}_{2}\right)$ complicated mode to $944 \mathrm{~cm}^{-1}[11]$ and Baraldi et al. assigned it to $939 \mathrm{~cm}^{-1}$ [13].

The $v_{\text {as }}(\mathrm{C}-\mathrm{S})_{\text {ring }}$ was observed at $704 \mathrm{~cm}^{-1}$ as a medium band in the IR and at $709 \mathrm{~cm}^{-1}$ as strong band in the Raman spectra. The $v_{s}(\mathrm{C}-\mathrm{S})_{\text {ring }}$ stretching was mixed with ring bending and observed at $644 \mathrm{~cm}^{-1}$ and $647 \mathrm{~cm}^{-1}$ in IR and Raman spectra, respectively. The bands at $782 \mathrm{~cm}^{-1}$ and $679 \mathrm{~cm}^{-1}$ were assigned to $\nu(\mathrm{C}-\mathrm{S})$ asymmetric and symmetric stretchings, respectively, by Cami et al. [34].

In this study, the band located at $675 \mathrm{~cm}^{-1}$ in the IR and at $680 \mathrm{~cm}^{-1}$ in the Raman spectrum was assigned to $\mathrm{w}\left(\mathrm{NH}_{2}\right)$ mode. This mode with a contribution of $\mathrm{CH}$ bending vibration was assigned to $636 \mathrm{~cm}^{-1}$ by Cami et al. [11]. There was no assignment corresponding to the $\mathrm{w}\left(\mathrm{NH}_{2}\right)$ mode in [13].

The ring torsion modes were expected in the region 530$650 \mathrm{~cm}^{-1}$. We assigned the $621 \mathrm{~cm}^{-1}$ and $582 \mathrm{~cm}^{-1}$ bands in IR spectrum and 637 and $580 \mathrm{~cm}^{-1}$ bands in the Raman spectrum to the ring torsion modes. These modes were observed at $650 \mathrm{~cm}^{-1}$ and $534 \mathrm{~cm}^{-1}$ by Cami et al. [11]. Baraldi et al. did not assign ring torsion modes [13]. However, the bands at $621 \mathrm{~cm}^{-1}$ in the IR spectrum and at $637 \mathrm{~cm}^{-1}$ in Raman spectrum were identified as $\delta_{\text {ip }}(\mathrm{N}-\mathrm{C}=\mathrm{O})$ mode [13], and the band at $584 \mathrm{~cm}^{-1}$ in IR spectrum and at $588 \mathrm{~cm}^{-1}$ in the Raman spectrum was assigned to $\delta \mathrm{SO}_{2}$ [24].

The acetazolamide $\mathrm{SO}_{2}$ wagging mode, coupled with $\mathrm{NH}_{2}$ wagging mode, was calculated at $535 \mathrm{~cm}^{-1}$ for free form. We did not observe this mode in the experimental IR or Raman spectra, but it was observed at $588 \mathrm{~cm}^{-1}$ [34] and at $552 \mathrm{~cm}^{-1}$ [11] in previous studies. This mode was assigned to $458 \mathrm{~cm}^{-1}$ in IR and $453 \mathrm{~cm}^{-1}$ in Raman spectra [24]. Rocking and twisting $\mathrm{SO}_{2}$ vibrations were situated at $416 \mathrm{~cm}^{-1}$ and $315 \mathrm{~cm}^{-1}$ [11]. In this study, corresponding values of these modes were assigned at $406 \mathrm{~cm}^{-1}$ and at $413 \mathrm{~cm}^{-1}$.

The assignment in the range of $500-250 \mathrm{~cm}^{-1}$ is difficult due to the presence of several overlapping weak bands. These bands are associated with vibrational and lattice modes and most of them are strongly overlapped.

The experimental micro-Raman (solid) and calculated (scaled) Raman intensity spectra and the experimental FT-IR (solid) and calculated (scaled) absorption intensity spectra of acetazolamide dimer (I-IV) are given in Figures 7 and 8.

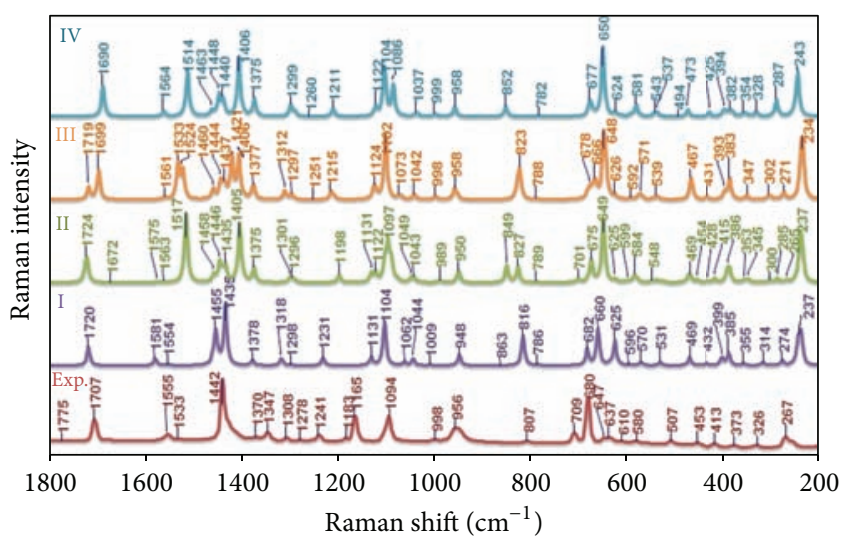

Figure 7: Experimental micro-Raman (solid) and calculated (scaled) Raman intensity spectra of acetazolamide dimer (I-IV) in the region $1800-200 \mathrm{~cm}^{-1}$, respectively.

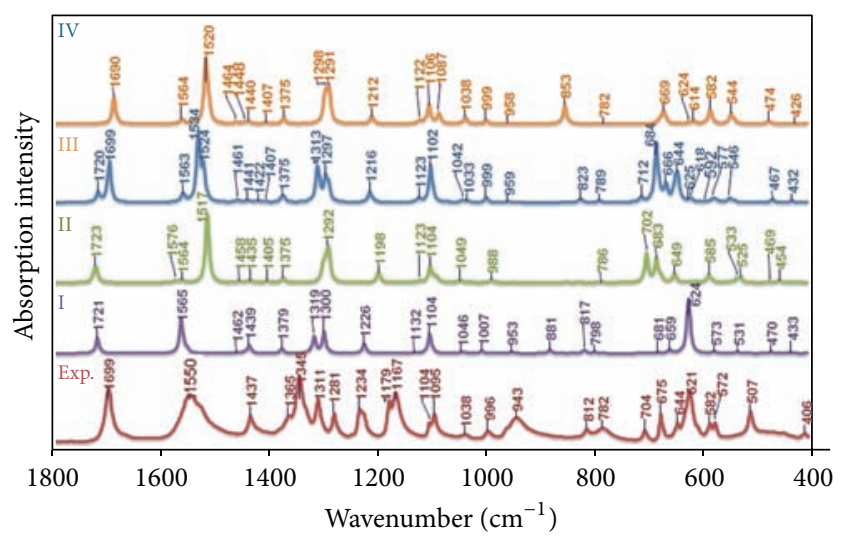

FIgURE 8: Experimental FT-IR (solid) and calculated (scaled) absorption intensity spectra of acetazolamide dimer (I-IV) in the region $1800-400 \mathrm{~cm}^{-1}$, respectively.

$\nu \mathrm{C}=\mathrm{O}, \nu \mathrm{C}=\mathrm{N}, \nu_{\mathrm{a}} \mathrm{SO}_{2}$, and $\nu_{\mathrm{s}} \mathrm{SO}_{2}$ vibrations are observed at $1699,1550,1346$, and $1168 \mathrm{~cm}^{-1}$, respectively, in the IR spectrum of solid acetazolamide, but they are observed at $1694\left(\Delta=v_{\text {aq. }}-v_{\text {solid }}=-5 \mathrm{~cm}^{-1}\right), 1552\left(\Delta=v_{\text {aq. }}-v_{\text {solid }}=\right.$ $\left.+2 \mathrm{~cm}^{-1}\right), 1344\left(\Delta=v_{\text {aq. }}-v_{\text {solid }}=-2 \mathrm{~cm}^{-1}\right)$, and $1166(\Delta=$ $\left.v_{\text {aq. }}-v_{\text {solid }}=-2 \mathrm{~cm}^{-1}\right)$ respectively, in that of aqueous solution. The water cluster structure (X) of Figure 3 simulates best the aqueous environment for the molecule. The experimental FT-IR (solid and aqueous solution) and calculated (scaled) absorption intensity spectra of $\mathrm{H}_{2} \mathrm{O}$ clusters (I-X) of acetazolamide in the region of $1800-800 \mathrm{~cm}^{-1}$ are given in Figure S2.

3.3. HOMO-LUMO and NBO Analysis. The frontier molecular orbitals are important in determining the molecular reactivity. The highest occupied molecular orbital (HOMO) energy characterizes the ability of electron giving, the lowest unoccupied molecular orbital (LUMO) energy characterizes the ability of electron accepting, and the gap between HOMO and LUMO characterizes the molecular stability. The HOMO 
and LUMO energies of acetazolamide are calculated by DFT method at B3LYP/6-31G ${ }^{* *}$ level of theory, and the atomic orbital compositions of the frontier molecular orbitals for acetazolamide are shown in Figure S3. LUMO is located over the ring, the methyl group, and $\mathrm{C}-\mathrm{N}$ bond which is located on the chain of the molecule. The HOMO is located over the ring, carbonyl group, and amine group, and consequently the homo-lumo transition implies an electron density transfer to ring, methyl group, and $\mathrm{C}-\mathrm{N}$ bond from the carbonyl group and amine group. The computed low HOMO-LUMO energy gap $(-5.497 \mathrm{eV})$ shows the charge transfer interactions, taking place within the molecule.

The NBO analysis of acetazolamide molecule is calculated by DFT method at B3LYP/6-31G*** level of theory. The nature and credibility of the intermolecular hydrogen bonding can be analysed by searching the changes in electron density in the environments of $\mathrm{N} \cdot \mathrm{H}$ hydrogen bonds. The $\mathrm{NBO}$ analysis of acetazolamide clearly explains the evidence of the formation of strong $\mathrm{H}$-bonded interaction between the $\mathrm{LP}(\mathrm{N})$ and $\sigma^{*}(\mathrm{~N}-\mathrm{H})$ antibonding orbitals. The hyperconjugative interactions $\mathrm{CR}\left(\mathrm{N}_{4}\right) \rightarrow \sigma^{*}\left(\mathrm{H}_{20}-\mathrm{N}_{21}\right), \mathrm{LP}_{1}\left(\mathrm{~N}_{4}\right) \rightarrow \sigma^{*}\left(\mathrm{H}_{20}-\right.$ $\left.\mathrm{N}_{21}\right)$, and $\mathrm{CR}\left(\mathrm{N}_{25}\right) \rightarrow \sigma^{*}\left(\mathrm{~N}_{12}-\mathrm{H}_{13}\right), \mathrm{LP}_{1}\left(\mathrm{~N}_{25}\right) \rightarrow \sigma^{*}\left(\mathrm{~N}_{12}-\right.$ $\mathrm{H}_{13}$ ) are obtained as $0.37,23.34,0.37$, and $23.34 \mathrm{kcal} / \mathrm{mol}$, respectively, and are shown in Table S4. The differences in $E^{2}$ energies are reasonably due to the fact that the accrual of electron density is in the $\mathrm{N}-\mathrm{H}$ bonds.

The comparison of $\mathrm{NBO}$ analysis between dimer and monomer forms of acetazolamide indicates the formation of two $\mathrm{H}$-bonded interactions between nitrogen lone electron pairs and $\sigma^{*}(\mathrm{~N}-\mathrm{H})$ antibonding orbitals.

The magnitudes of charge transfer from lone pairs of $n\left(\mathrm{~N}_{4}\right)$ and $n\left(\mathrm{~N}_{25}\right)$ of the hydrogen-bonded $\mathrm{N}$ atoms into the antibonds $\sigma^{*}\left(\mathrm{~N}_{21}-\mathrm{H}_{20}\right)$ and $\sigma^{*}\left(\mathrm{~N}_{12}-\mathrm{H}_{13}\right)$ increased upon dimerization (0.05298e and 0.05299e) (see Table S5). Similar conclusion can be obtained while considering the energy of each orbital. The electron density in the $\mathrm{N}-\mathrm{H}$ antibonding orbitals $\sigma^{*}\left(\mathrm{~N}_{4}-\mathrm{C}_{5}\right)$ and $\pi^{*}\left(\mathrm{~N}_{4}-\mathrm{C}_{5}\right)$ is increased significantly $(0.00291$ e and 0.04037 e, resp.) because of the dimerization. The elongation $(0.02 \AA)$ thereby weakens the bond. This is associated with the downshifts of stretching frequency (Table S2 and Table 3).

The intramolecular hyperconjugative interaction $\sigma\left(\mathrm{N}_{4}-\right.$ $\left.\mathrm{C}_{5}\right)$ distribution to $\sigma^{*}\left(\mathrm{C}_{5}-\mathrm{N}_{12}\right)$ and $\sigma^{*}\left(\mathrm{~N}_{12}-\mathrm{C}_{14}\right)$ caused less stabilization of 1.09 and $2.06 \mathrm{kcal} / \mathrm{mol}$. This interaction of $\pi\left(\mathrm{N}_{4}-\mathrm{C}_{5}\right)$ with $\pi^{*}\left(\mathrm{C}_{2}-\mathrm{N}_{3}\right)$ leads to strong delocalization of $14.11 \mathrm{kcal} / \mathrm{mol}$. There occurs a strong intramolecular hyperconjugative interaction from $n\left(\mathrm{~N}_{12}\right)$ to $\sigma^{*}\left(\mathrm{~N}_{4}-\mathrm{C}_{5}\right)$ and $\sigma^{*}\left(\mathrm{C}_{14}-\mathrm{O}_{15}\right)$ with 47.21 and $54.82 \mathrm{kcal} / \mathrm{mol}$ (Table S4). The increased electron density at the $\mathrm{N}_{12}$ atom leads to the elongation of $\mathrm{N}-\mathrm{H}$ bond and a lowering of the $\mathrm{N}-\mathrm{H}$ stretching wavenumber (see Table S2 and Table 3).

\section{Conclusion}

In this study, the monomer and dimer forms and water clusters of acetazolamide were studied by using the DFT method at B3LYP/6-31G++(d,p) level of theory. The effect of basis set superposition error (BSSE) on the structure and energy of acetazolamide dimer has been investigated. The most stable structure of the dimer (dimer I) possesses interaction energy of $16.116 \mathrm{kcal} / \mathrm{mol}$ after the basis set superposition error (BSSE) correction. The difference between the BSSE corrected $(16.116 \mathrm{kcal} / \mathrm{mol})$ and uncorrected $(17.390 \mathrm{kcal} / \mathrm{mol})$ interaction energies indicates the magnitude of error caused due to the basis set superposition. The energy of dimer I is found to be lower than the total energy of the two monomer $\left(2^{*} E_{\text {monomer }}\right)$ units, indicating that intermolecular hydrogen bonding plays an important role in stabilization of the molecule. The wavenumbers associated with the related molecule are in a good agreement with $[11,34]$. The comparison of NBO analysis between dimer and monomer forms of acetazolamide indicates the formation of two H-bonded interactions between nitrogen lone electron pairs and $\sigma^{*}(\mathrm{~N}-$ $\mathrm{H})$ antibonding orbitals. Increasing of the electron density in the $\mathrm{N}-\mathrm{H}$ antibonding orbitals upon dimerization can be associated with the downshifts of $\mathrm{N}-\mathrm{H}$ stretching frequency.

\section{Acknowledgment}

This study was supported by the Research Funds of Istanbul University (Project nos. ONAP-2423, UDP-16156, and UDP17069-N-3341).

\section{References}

[1] I. P. Kaur, R. Smitha, D. Aggarwal, and M. Kapil, "Acetazolamide: future perspective in topical glaucoma therapeutics," International Journal of Pharmaceutics, vol. 248, no. 1-2, pp. 1-14, 2002.

[2] S. Chakravarty and K. K. Kannan, "Drug-protein interactions. Refined structures of three sulfonamide drug complexes of human carbonic anhydrase I enzyme," Journal of Molecular Biology, vol. 243, no. 2, pp. 298-309, 1994.

[3] S. C. Sweetman, Ed., Martindale: The Complete Drug Reference, Pharmaceutical Press, London, UK, 32nd edition, 1999.

[4] N. A. Kasim, M. Whitehouse, C. Ramachandran et al., "Molecular properties of WHO essential drugs and provisional biopharmaceutical classification," Molecular Pharmacology, vol. 1, no. 1, pp. 85-96, 2004.

[5] C. T. Supuran, "Carbonic anhydrases: novel therapeutic applications for inhibitors and activators," Nature Reviews Drug Discovery, vol. 7, pp. 168-181, 2008.

[6] B. A. Teicher, S. D. Liu, J. T. Liu, S. A. Holden, and T. S. Herman, "A carbonic anhydrase inhibitor as a potential modulator of cancer therapies," Anticancer Research, vol. 13, no. 5, pp. 15491556, 1993.

[7] C. T. Supuran, F. Briganti, S. Tilli, W. R. Chegwidden, and A. Scozzafava, "Carbonic anhydrase inhibitors: sulfonamides as antitumor agents?" Bioorganic and Medicinal Chemistry, vol. 9, no. 3, pp. 703-714, 2001.

[8] G. Pala, "Ultraviolet and infrared absorption of 2-acetylamino1, 3, 4-thiodiazole-5-sulfonamide," Il Farmaco. Edizione Scientifica, vol. 11, no. 4, pp. 395-403, 1956.

[9] M. Mathew and G. J. Palenik, "Crystal and molecular structure of acetazolamide (5-acetamido-1,3,4-thiadiazole-2sulphonamide), a potent inhibitor of carbonic anhydrase," Journal of the Chemical Society, Perkin Transactions 2, no. 5, pp. 532-536, 1974. 
[10] U. J. Griesser, A. Burger, and K. Mereiter, "The polymorphic drug substances of the european pharmacopoeia, part 9. Physicochemical properties and crystal structure of acetazolamide crystal forms," Journal of Pharmaceutical Sciences, vol. 86, no. 3, pp. 352-358, 1997.

[11] G. E. Cami, E. E. Chufan, J. C. Pedregosa, and E. L. Varetti, "Infrared and Raman spectra of 5-amino-1, 3, 4-thiadiazole-2sulfonamide (Hats). Experimental data and quantum chemistry calculations," Journal of Molecular Structure, vol. 570, no. 1-3, pp. 119-127, 2001.

[12] J. C. Pedregosa, G. Alzuet, J. Borras, S. Fustero, S. GarciaGranda, and M. R. Diaz, "Structure of 5-amino-1, 3, 4thiadiazole-2-sulfonamide, an inhibitor of the enzyme carbonic anhydrase," Acta Crystallographica C, vol. 49, no. 3, pp. 630-633, 1993.

[13] C. Baraldi, M. C. Gamberini, A. Tinti, F. Palazzoli, and V. Ferioli, "Vibrational study of acetazolamide polymorphism," Journal of Molecular Structure, vol. 918, no. 1-3, pp. 88-96, 2009.

[14] S. Ferrer, J. Borras, C. Miratvilles, and A. Fuertes, "Synthesis and characterization of copper(II)-acetazolamide (5-acetamido1,3,4-thiadiazole-2-sulfonamide) complexes. Crystal structure of dimeric $[\mathrm{Cu}(\mathrm{Acm})(\mathrm{NH} 3) 2(\mathrm{OH} 2)] 2 . c n t d o t .2 \mathrm{H} 2 \mathrm{O}$," Inorganic Chemistry, vol. 29, no. 2, pp. 206-210, 1990.

[15] S. Ferrer, J. Borras, C. Miratvilles, and A. Fuertes, "Masthead," Inorganic Chemistry, vol. 28, no. 1, pp. 160-163, 1989.

[16] J. C. Pedregosa, J. Casanova, G. Alzuet et al., "Metal complexes of 5-tertbutyloxycarbonylamido-1,3,4-thiadiazole-2-sulfonamide ( $\mathrm{B}-\mathrm{H}_{2}$ ats), a carbonic anhydrase inhibitor. synthesis and characterization of the copper(II) complex. crystal structures of $\mathrm{B}-\mathrm{H}_{2}$ ats and the $\left[\mathrm{Cu}(\mathrm{B} \text {-ats })\left(\mathrm{NH}_{3}\right)_{2}\right]_{2}$ dimer complex," Inorganica Chimica Acta, vol. 232, no. 1-2, pp. 117-124, 1995.

[17] J. C. Pedregosa, J. Borras, S. Fustero, S. Garcia-Granda, and M. R. Diaz, "A new precursor of 1,3,4-thiadiazolesulfonamides: 5tert-butyloxycarbonylamino-1,3,4-thiadiazole-2-sulfonyl chloride," Acta Crystallographica C, vol. 52, no. 7, pp. 1849-1851, 1996.

[18] E. E. Chufan, J. C. Pedregosa, and J. Borras, "Spectroscopic behaviour of metal-drug complexes. infrared spectra of $\mathrm{Cu}(\mathrm{II})$ complexes with 5-amino-1, 3, 4-thiadiazole-2-thiol (Hatm)," Vibrational Spectroscopy, vol. 15, no. 2, pp. 191-199, 1997.

[19] E. E. Chufan, J. C. Pedregosa, S. Ferrer, and J. Borras, "Spectroscopic behavior of metal-drug complexes. Infrared spectra of $\mathrm{Cu}$ (II) dimer complexes with acetazolamide $\left(\mathrm{H}_{2} \mathrm{acm}\right)$ and an analogue sulfonamide (B- $\mathrm{H}_{2}$ ats)," Vibrational Spectroscopy, vol. 20, no. 1, pp. 35-45, 1999.

[20] G. Cami, J. Server-Carrio, S. Fustero, and J. C. Pedregosa, Acta Crystallographic C, vol. 56, pp. 209-210, 2000.

[21] E. E. Chufan, S. Garcia-Granda, M. R. Diaz, J. Borras, and J. C. Pedregosa, "Several coordination modes of 5-amino1,3,4-thiadiazole-2-sulfonamide (Hats) with $\mathrm{Cu}(\mathrm{II}), \mathrm{Ni}(\mathrm{II})$ and $\mathrm{Zn}(\mathrm{II})$ : mimetic ternary complexes of carbonic anhydraseinhibitor," Journal of Coordination Chemistry, vol. 54, no. 3-4, pp. 303-312, 2001.

[22] M. Liu-Gonzalez, F. Sanz-Ruiz, E. E. Chufán, J. C. Pedregosa, and J. Borras-Tortonda, "Bis(diethylenetriamine- $\kappa 3 \mathrm{~N}$ )nickel (II) 5-amino-1,3,4-thiadiazole-2-sulfonamidate chloride monohydrate," Acta Crystallographica C, vol. 57, no. 10, pp. 1132-1134, 2001.

[23] U. Hartmann and H. Vahrenkamp, "A zinc complex of the carbonic anhydrase inhibitor acetazolamide (aaH): crystal structure of (aaa)2Zn(NH3)2," Inorganic Chemistry, vol. 30, no. 24, pp. 4676-4677, 1991.
[24] S. A. Brandan, E. Eroglu, A. E. Ledesma, O. Oltulu, and O. B. Yalcinkaya, "A new vibrational study of Acetazolamide compound based on normal coordinate analysis and DFT calculations," Journal of Molecular Structure, vol. 993, no. 1-3, pp. 225231, 2011.

[25] D. Chaturvedi, V. Gupta, P. Tandon, A. Sharma, C. Baraldi, and M. C. Gamberini, "Intermolecular charge transfer and vibrational analysis of hydrogen bonding in acetazolamide," Spectrochimica Acta A, vol. 99, pp. 150-159, 2012.

[26] M. J. Frisch, G. W. Trucks, H. B. Schlegel et al., Gaussian 03, Revision C. 02, Gaussian, Wallingford, Conn, USA, 2004.

[27] K. Balci and S. Akyuz, "A vibrational spectroscopic investigation on benzocaine molecule," Vibrational Spectroscopy, vol. 48, no. 2, pp. 215-228, 2008.

[28] J. M. L. Martin and C. Van Alsenoy, GAR2PED: A Program to Obtain a Potential Energy Distribution from a Gaussian Archive Record, University of Antwerp, Antwerp, Belgium, 2007.

[29] S. F. Boys and F. Bernardi, "The calculation of small molecular interactions by the differences of separate total energies. some procedures with reduced errors," Molecular Physics, vol. 19, no. 4, pp. 553-566, 1970.

[30] A. Foldes and C. Sandorfy, "Anharmonicity, solvent effects, and hydrogen bonding: NH stretching vibrations," Canadian Journal of Chemistry, vol. 48, no. 14, pp. 2197-2203, 1970.

[31] Y. Tanaka and K. Machida, "Anharmonicity of $\mathrm{NH}_{2}$ stretching vibrations of aniline," Journal of Molecular Spectroscopy, vol. 51, no. 3, pp. 508-519, 1974.

[32] Y. Tanaka and K. Machida, "Anharmonicity of $\mathrm{NH}_{2}$-stretching vibrations of substituted anilines," Journal of Molecular Spectroscopy, vol. 55, no. 1-3, pp. 435-444, 1975.

[33] W. J. Hehre, L. Radom, P. V. R. Schleyer, and J. A. Pople, Ab Initio Molecular Orbital Theory, Wiley, New York, NY, USA, 1986.

[34] G. E. Cami, M. C. Ramirez de Arellano, S. Fustero, and J. C. Pedregosa, "Synthesis, growth and characterization of new 1, 3, 4-thiadiazole-5-(N-substituted)-sulfonamides crystals," The Journal of the Argentine Chemical Society, vol. 94, no. 4-6, pp. 5-17, 2006. 

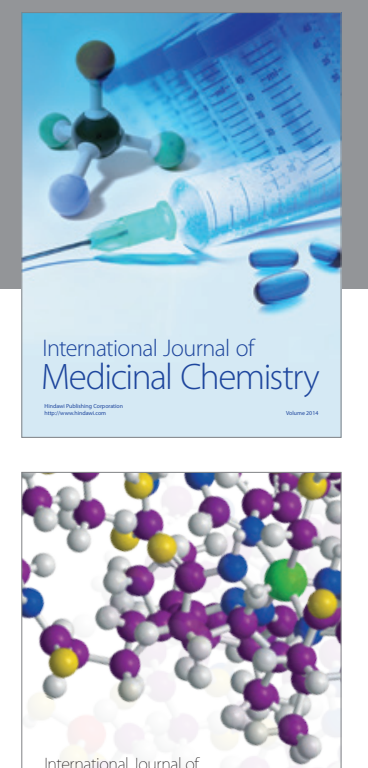

\section{Carbohydrate} Chemistry

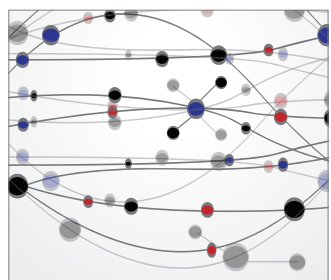

The Scientific World Journal
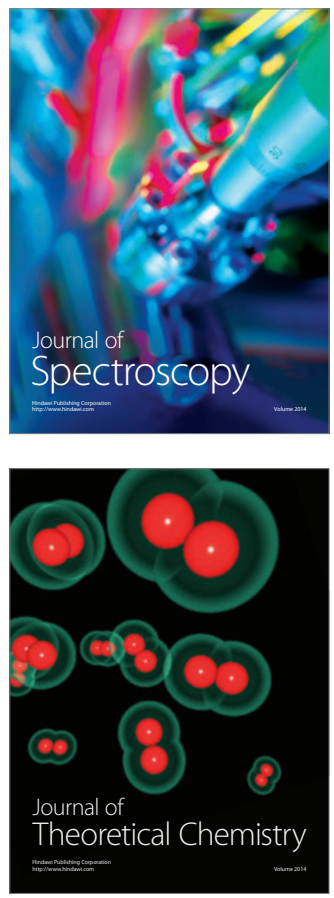
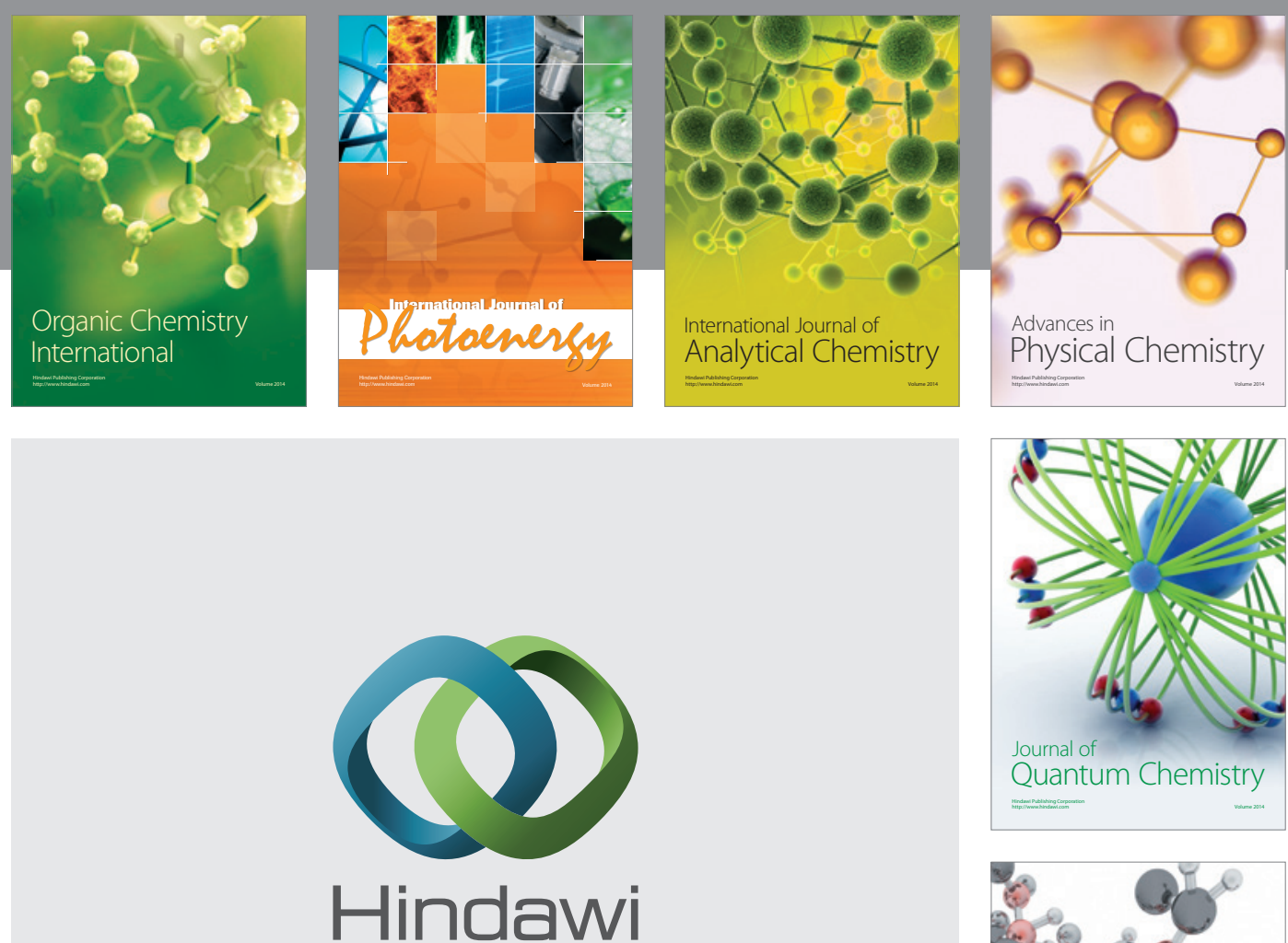

Submit your manuscripts at

http://www.hindawi.com

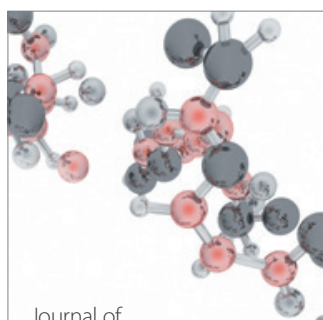

Analytical Methods

in Chemistry

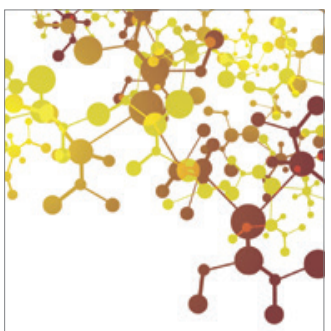

Journal of

Applied Chemistry

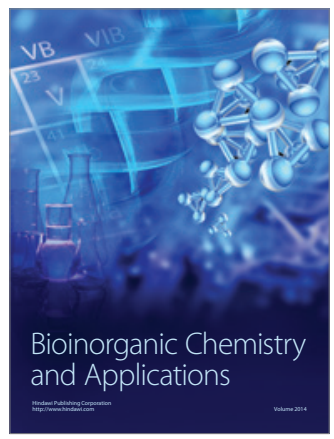

Inorganic Chemistry
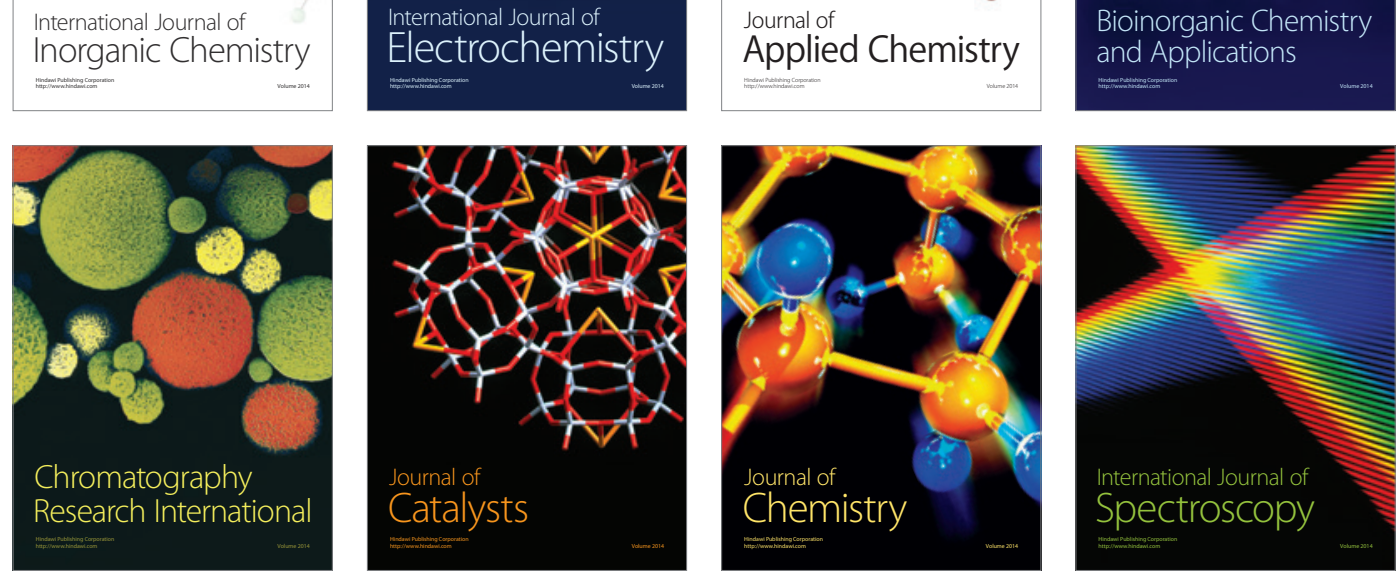